\title{
Histochemical and Autoradiographic Studies on the Ovarian Morphogenesis of Rat
}

\author{
Ichiro KOKETSU \\ Department of Obstetrics and Gynecology, Kobe University School of Medicine, Kobe, Japan \\ (Director : Professor Shimpei Tojo, M.D.)
}

In order to elucidate the growth and differentiation process of the rat ovary and its histogenesis, histochemical and autoradiographic 'studies on the ovarian morphogenesis have been performed, and the following findings have been obtained.

Histological findings: 1) After the neonatal stage, no germ cells could be observed. 2) On the seventh day after the birth the secondary follicles appeared besides the primordial follicles. 3) The tertiary follicles and the primary interstitial tissue appeared about 14 days after the birth. 4) The diameter of oocyte increased with growth of follicles and reached the peak in the tertiary follicles. 5) Vesicular follicles, atretic follicles, and secondary interstitial tissue emerged at about 21 days after the birth. 6) The atretic process of follicles could be classified in three types. The cells of the secondary interstitial tissue were found to come from thecal cells.

Histochemical findings: Increased lactic dehydrogenase activity was observed in the epithelium of primordial, primary and secondary follicles at about three and seven days after the birth. Glucose-6-phosphatase activity was very weak. Increased glucose-6phosphatase activity, however, was observed in the tertiary follicles. This suggests that anaerobic glycolytic system plays the main role in the carbohydrate metabolism of the small follicular epithelium. In the interstitial cells and thecal cells, in addition to intense steroid $3 \beta$-ol dehydrogenase and glucose-6-phosphatase activity the presence of lipid granules could be demonstrated.

Autoradiographical findings: 1) By the migration method, it could be clarified that the follicular and thecal cells come from undifferentiated stromal cells and that the primary interstitial tissue comes from undifferentiated stromal cells. 2) When examined by the pulse labeling method, the follicular epithelium incorporation of ${ }^{3} \mathrm{H}$-thymidine was low in the primordial and primary follicles, but rose with the growth of the follicles. The incorporation of ${ }^{3} \mathrm{H}$-thymidine, however, decreased in cyst-formed large follicles. The incorporation was noted in the primary but not in the secondary interstitial tissue. In view of the findings that the incorporation of interstitial cells decreased with the rise of the animal's age, it may be presumed that gain in weight of ovarian connective tissue is not necessarily due to the preliferation of mesenchym in situ.

(See pp. 101 114) 


\title{
ラット卵巣の発育過程に関する機能形態学的研究
}

\author{
神戸大学医学部産科婦人科学教室（主任 東條伸平教授） \\ 古 結 一 郎
}

（昭和47年 2 月 22 日受村）

卵巣の発育分化過程や組織由来を検討し，以下の結果を得た。

縕織学的所見：新生期以後では germ cell は認められず，生後 7 日目に原始卵胞の他に第二次卵胞が 出現した。第三次卵胞，第一次間質腺は生後14日目前後から出現した。卵紏胞直径は卵胞の発育と共に 増大し，第三次卵胞で頂点に達した．胞状卵胞，閉鎖卵胞，第二次間質腺は生後21日前後から出現した。 卵胞の閉鎖過程より，第二次間質腺細胞は内膜細胞に由来するとの結果を得た.

組織化学的所見：生後 3 日目，7 日目頃の原始，第一次，第二次卵胞上皮に強い LDH 活性をみたが， G-6-PDH 活性は極めて弱かつた。 しかし第三次卵胞で G-6-PDH 活性の増加がみられた。

このことから小卵胞上皮の糖代謝は㜖気的解糖系が主体をなすと推察された。間質細胞，内莢膜細胞

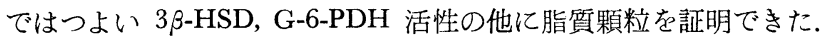

Autoradiograph 所見：migration 法より卵胞，内荻膜細胞，第一次間筑細胞は未分化間質細胞に由 来するととを明かにした。 pulse labeling 法により， ${ }^{3} \mathrm{H}$-thymidine は第一次間質腺には取り込みがあ つたが，第二次間質腺では取り込みが見られなかつた．卵巣結合織の増量は間質細胞のとり込みが経令 的に減少するので必ずしも in situ mesenchym の増殖に基くものではないと推測された。

はじめに

従来, 幼時期や小児期の卵樂は静的な器官と見做されていた。しかしてうした見方は卵巢の二大機能即ち 卵成熟能とステロイド産生能のうち，主に後者に立脚したもので, 形態学的にはての時期から極めて動的な 分化，形成過程が惹起されている．著者はての間の実態をより詳細に追究するてとにより卵巣各要素の組織 由来, その形態分化の示唆する機能的意義, ひいては幼仔卵楽の内分泌機能の寒態, 卵巣の tumorigenesis などを考察する上での重要な基礎的な知見が得られるであろうと考え，以下の如き研究を行つた。

\section{I 実 験 方 法}

\section{A. 実験材料}

Spraque-Dowley 系雌ラットを用いたが，乙れらの膣開口期は，生後ほぼ第 $6 〜 7$ 週であつた，

\section{B. 実験方法}

1. 組織学的検索方法として Hematoxylin-eosin 染色, Mallory-Azan 染色, 鍍銀染色法 (Pap 氏法, 鈴木氏法) を, 組織化学的検索方法として, Sudan black 染色, Sudan III 染色, $3 \beta$-HSD 活性（Wattenberg の変法, 基質 : DHA), G-6-PDH 活性（Nachlas の変法）, LDH 活性（Nachlas の変法）を行い, また， ${ }^{3} \mathrm{H}$-thymidine を用いて autoradiograph を作製，目的に応じ migration 法（生直後のラットに 10 $\mu \mathrm{ci}$ を腹腔内投与し， 2 時間， 3 日，7日，14日後に屠殺），あるいは pulse labeling 法 ( ${ }^{3} \mathrm{H}$-thymidine を体重 $1 \mathrm{gr}$ 当り $10 \mu \mathrm{ci}$ 腹腔内投与し， 2 時間後に屠殺）を実施した。

また，卵栄各要素の thymidine の取り込み状態を知るべく㯲識細胞数を数え，同一細胞群内の百分率， すなわち, thymidine index で表示した。

2. 卵胞直径を接眼 micro-meter 苍用いて測定し, 卵数は卵巣の最大面標本から240倍の顕微鏡写真を作 
成し，てれから算定した。

3. 胚上皮高の計測は, 対物レンズ百倍の拡大で接眼 micro-meter を用いて計測し, 生直後の厚さを 100 \%として以後の時期における胚上皮㟄の厚さを百分率で表わし，比較検討した。

4. 卵胞の発育段階は卵細胞を囲屯卵胞上皮細胞数によつてFig. 2 の如く前原始卵胞, 原始卵胞, 第一次 卵胞，第二次卵胞，第三次卵胞および胞状卵胞に分類した.

\section{II 実 験 結 果}

\section{1 生後 1 日目の卵巣}

A 組織学的所見 : 生直後のラット卵巣の構成要素は, 主に卵細胞, 未分化間質細胞, 及び肧上皮の三者 で，卵細胞は門部に少く，皮質外側部に Gitter 線維に囲まれ一塊となつて群集し，胈上直皮下には横走す る䀘銀線維が認められた。卵細胞の核分裂状態は late prophase, ことに diplotene stage のものが多く, また一塊として密接する卵細胞はたがいに同調するかの如くほぼ分裂状態を一にしていた．

また卵細胞の核が濃染し，辺縁のいびつな閉鎖卵が中等数認められた。こうした卵細胞巣の周囲には紡錘 形の, 細胞質に比較的乏しい未分化間質細胞が分布していた。 また，乙とに生直後のての時期から生後 7 日 迄の間，恹上皮内に多数の卵細胞を，同時に上皮直下の譛銀線維を破るが如く上皮層内に侵入中の卵細胞を， さらに，上皮が解離し，てれを経由し，卵細胞が卵巣囊内一放出されたと見てよい所見も認められた。

他方血管系の発達は門部, 皮質を通じて極めて貧であつた。

B. Autoradiograph 所見：pulse labeling 法による thymidine の取り込みは，卵細胞では全く認めら れなかつたが，未分化間質細胞には強い取り込み（thymidine index：25\%) を見た。このほか，肧上皮細 胞にも取り込みがある (thymidine index：5\%).

Fig. 1. Thickness of the germinal epithelium, the diameter of oocyte and oocyte reduction.

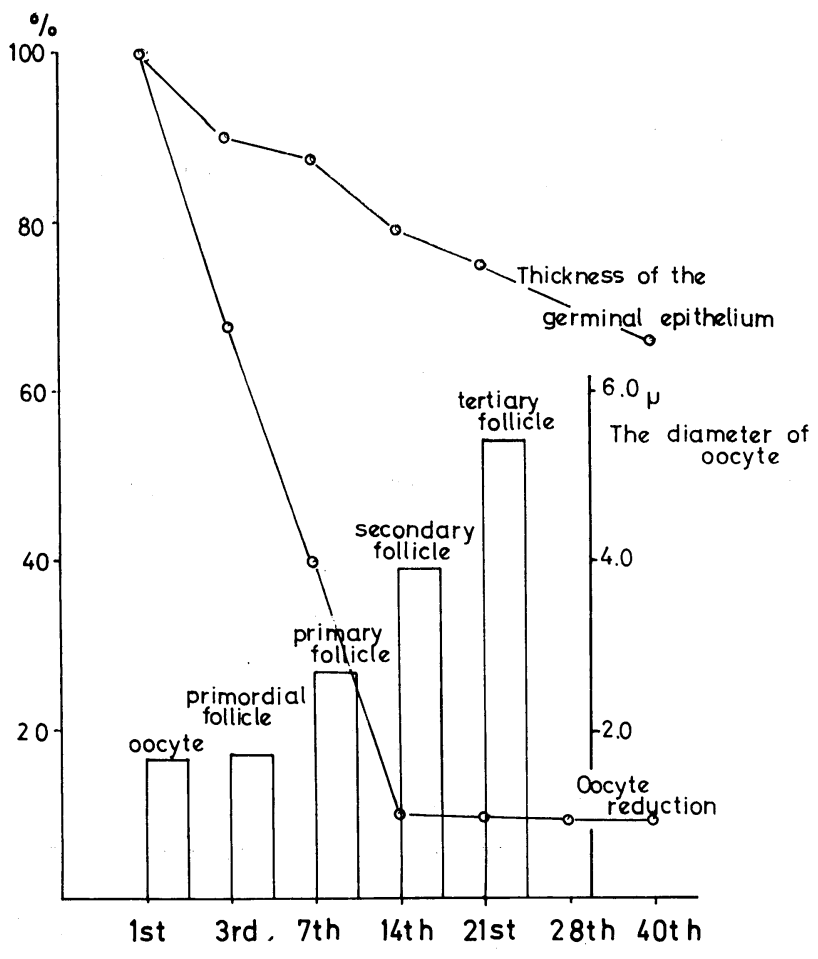

第 48 巻 第 2 号 


\section{2 生後 3 日目の卵巣}

A 組織学的所見: 前述の卵細胞集団は互いに分離しはじめ, 卵細胞の核分裂状態も dictyate stage に移 行しているものが多かつた。

卵胞発育は一般に皮質中央部ほど良好で 5 佔前後の卵胞上皮細胞を有するもの (preprimordial follicle) から10個前後の卵胞上皮細胞で卵の周囲を完全にとりかてむ原始卵胞，さらに第一次卵胞が存在していた。し かしての時期では，まだ第三次卵胞は無論のとと，第二次卵胞も見られなかつた。

肧上皮細胞は依然高円柱状，偽重層状を呈し，中等数の分裂像が見られた。

B 組織化学的所見 : G-6-PDH, LDH, 3 $\beta$-HSD 諸酵素活性について検討したが, 肧上皮細胞のみに LDH 活性が見られた.

Fig. 2. Count of follicles per ovary according to the number of granulosa cells in the section where the nucleolus of the oocyte was seen

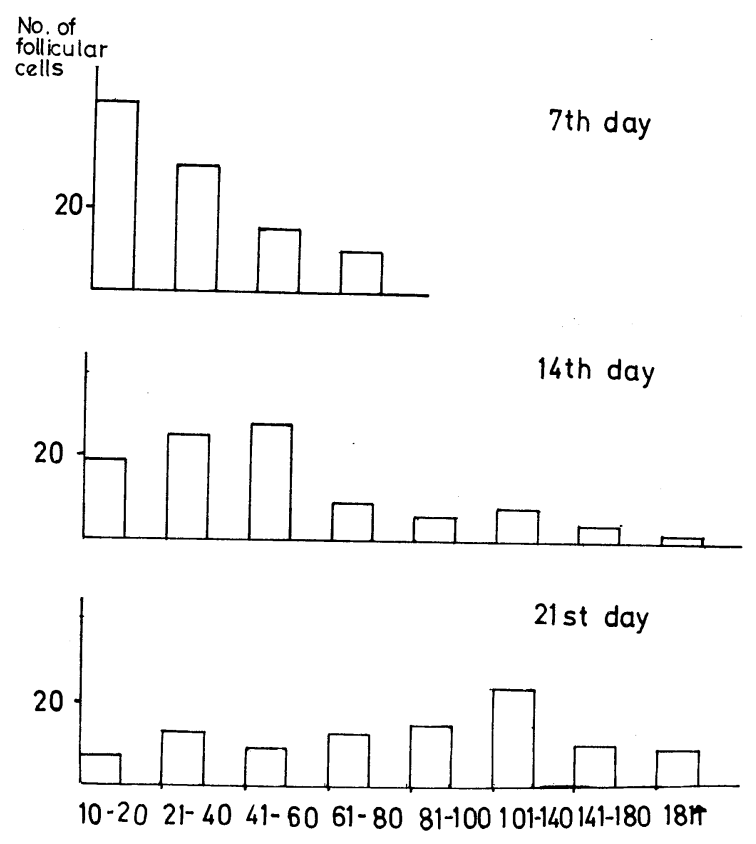

\begin{tabular}{|c|c|c|c|c|c|}
\hline Name & oocyte $\begin{array}{c}\text { pre primordial primordial } \\
\text { follicle }\end{array}$ & $\begin{array}{l}\text { primary } \\
\text { follicle }\end{array}$ & $\begin{array}{l}\text { secondary } \\
\text { follicle }\end{array}$ & $\begin{array}{l}\text { tertiary follicle } \\
\text { small }\end{array}$ & tertiary follicle \\
\hline $\begin{array}{l}\text { number of } \\
\text { granulosa } \\
\text { cells }\end{array}$ & $0-4-5-10$ & $11-20$ & $21-80$ & $81-180$ & 180 \\
\hline & (2) ஒ (2) & \% & 想 & & \\
\hline
\end{tabular}


C. Autoradiograph 所見 : migration 法で, ${ }^{3} \mathrm{H}$-thymidine の原始卵胞上皮への移動が証明できた.さ らに pulse labeling 法での原始卵胞細胞の ${ }^{3} \mathrm{H}$-thymidine の取り込み率は未分化間質細胞や migration 法 での卵胞細胞の夫に比し著明に低い值を得たが preprimordial follicle の取り込みは高い值（thymidine index 20\%) を示していた。

\section{3 生後 7 日目の卵宩}

A 組織学的所見：卵細胞核の核小体がみられる卵胞はほぼ最大割面に一致するという知見に基き，核小 体のみられる卵胞の卵胞上皮細胞数を数え, その発育状態を追求した結果Fig. (2)の如く, 卵胞上皮細胞数 10 〜20の第一次卵胞が最も多く，21〜40の卵胞がてれにつぎ，以下41〜60，61〜80の第二次卵胞の順であつた. 即ち原始卵胞，第一次卵胞のほかに，第二次卵胞が出現したが，てうした一部の第二次卵胞では卵胞上皮基 底膜の閉鎖がしばしば不完全で，乙の部では不正形〜半円錐形の卵胞細胞集団をみ，間質紐胞との境界は必 ずしも明瞭でなかつた。また第二次卵胞の外側部を不㓂全ながらとりまく未分化間質細胞は莢膜細胞様の形 態，配位を示していた。 また不完全ながら，Call-Exner body 初期段階の腔形成をみる卵胞もある。

卵細胞は完全に分離され，その核分裂状態は全て核小体の明瞭な dictyate stage に移行し，第二次卵胞の 卵細胞直径は原始卵胞，第一次卵胞に比し明らかに増大していた。

一方，未分化間質細胞は肥大し，間質細胞様となる．また，生後 3 日目で偽重層を呈していた脤上皮は， 一層の立方〜円柱状の配列を示し， mitosis も減数していた。このほか原始卵胞が胚上皮に突出し，その尖 端部の卵胞細胞は消失し，著しく偏平化した脹上皮のみで覆われている像も見られた。なお，泼上皮の down growth 像は著者の全観察期間を通じみられなかつた.

B 組織化学的所見: 胚上皮, 卵細胞, 卵胞上皮, 未分化間覧細胞に LDH 活性㐬認めたが, その活性強

Table 1. Histochemical findings of rat ovary (1) $3 \beta$-HSD activity

\begin{tabular}{|c|c|c|c|c|c|c|}
\hline & 7 th day & 14 th day & 21 st day & 28 th day & 40 th day & 54 th day \\
\hline $\begin{array}{l}\text { germinal } \\
\text { epithelium }\end{array}$ & - & - & - & - & - & - \\
\hline $\begin{array}{l}\text { primordial } \\
\text { follicle }\end{array}$ & - & - & - & - & - & - \\
\hline $\begin{array}{l}\text { primary } \\
\text { follicle }\end{array}$ & - & -- & - & - & - & - \\
\hline $\begin{array}{l}\text { secondary } \\
\text { follicle }\end{array}$ & - & - & - & - & - & - \\
\hline $\begin{array}{l}\text { tertiary } \\
\text { follicle }\end{array}$ & $\begin{array}{l}\text { granulosa } \\
\text { theca }\end{array}$ & $\begin{array}{c}\dot{\circ} \sim+ \\
+\end{array}$ & $\begin{array}{c}- \\
+\sim H\end{array}$ & $\begin{array}{c}- \\
+\sim H\end{array}$ & - & - \\
\hline $\begin{array}{l}\text { vesicular } \\
\text { follicle }\end{array}$ & $\begin{array}{c}\text { granulosa } \\
\text { theca }\end{array}$ & $\gamma$ & $\begin{array}{c}- \\
+\sim H\end{array}$ & $\begin{array}{l}-o r+ \\
+\sim H\end{array}$ & $\begin{array}{c}- \text { or }+ \\
\text { H }\end{array}$ & $\begin{array}{c}- \text { or }+ \\
H\end{array}$ \\
\hline $\begin{array}{l}\text { primary } \\
\text { interstitial } \\
\text { tissue }\end{array}$ & $\zeta$ & $+\sim H$ & + & $\div$ & / & $\zeta$ \\
\hline $\begin{array}{l}\text { secondary } \\
\text { interstitial } \\
\text { tissue }\end{array}$ & / & $\gamma$ & H & $H \sim H$ & H & H \\
\hline $\begin{array}{l}\text { atretic } \\
\text { follcle }\end{array}$ & $\begin{array}{c}\text { granulosa } \\
\text { theca }\end{array}$ & $\gamma$ & $\begin{array}{l}+ \\
+\end{array}$ & $\begin{array}{c}+ \\
H \sim H\end{array}$ & $\begin{array}{c}+ \\
\text { H }\end{array}$ & $\begin{array}{l}+ \\
+\end{array}$ \\
\hline $\begin{array}{l}\text { corpus } \\
\text { luteum }\end{array}$ & 1 & & $/$ & / & 1 & . \\
\hline
\end{tabular}


G-6-PDH activity

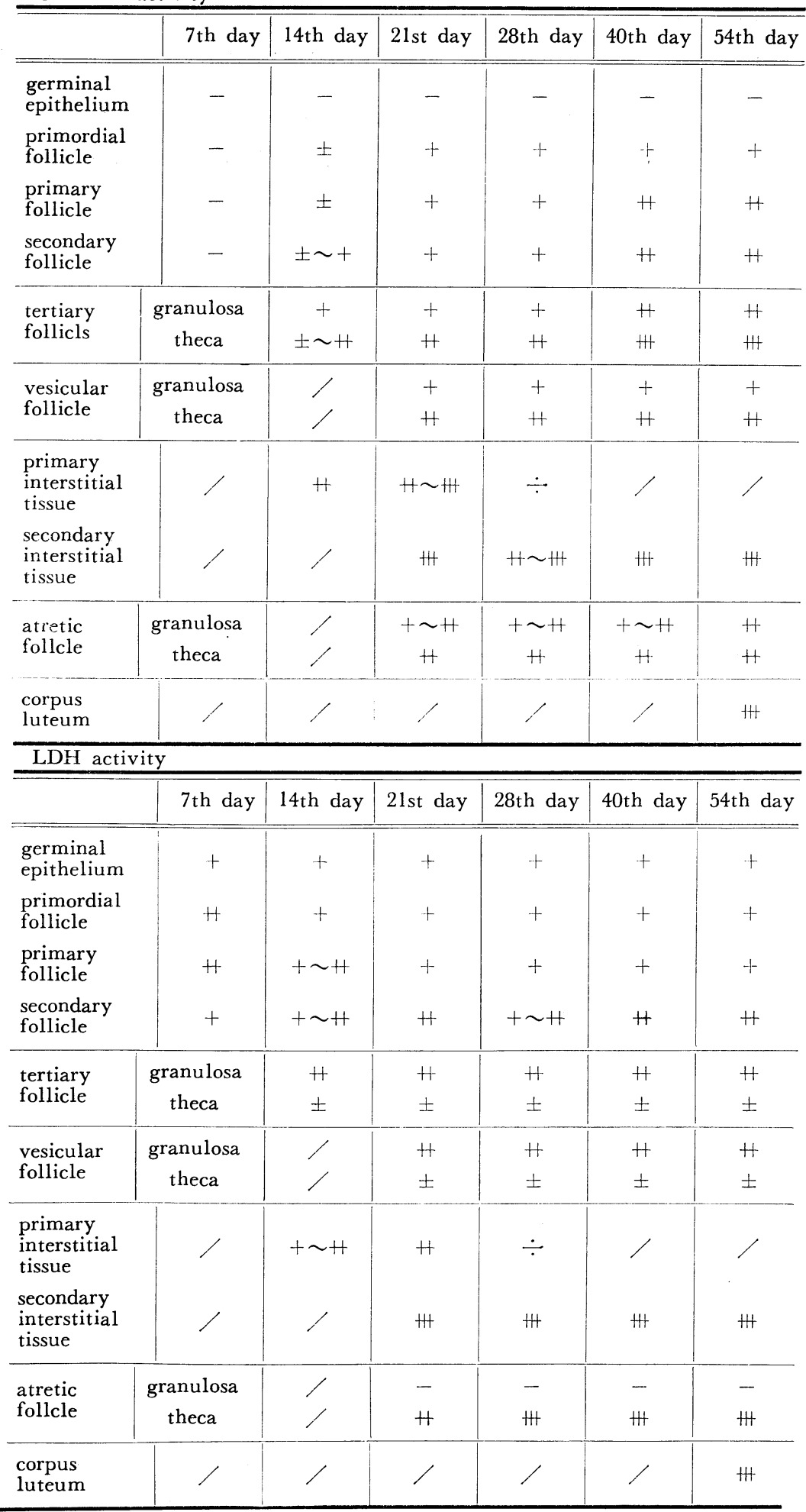


度は原始卵胞上皮が最も強く, 第二次卵胞上皮, 肧上皮, 未分化間質細胞, 卵細胞の順に弱く, 卵細胞では ミトコンドリア部に相当して活性がみられた。他方卵胞上皮，未分化間質細胞の G-6-PDH 活性は依然殆ん ぞ認められず, $3 \beta-H S D$ 活性も陰性であつた。

C. Autoradiograph 所見：migration 法で銀粒子の第二次卵胞上皮への移行が証明できた. また, pulse labeling 法汇よる所見では，卵胞発育が進んだ卵胞ほど卵胞上皮の ${ }^{3} \mathrm{H}$-thymidine の取り込み率が増加し， 未分化間質細胞では, 生直後や生後 3 日目と比較して減少していた。

\section{4 生後14日目の卵巣}

A 組織学的所見：ての時期では卵胞腔を有する第三次卵胞が出現したが, 卵胞の発育状況はFig. (2)の様 である. 第三次卵胞の卵胞上皮は第二次卵胞に比しょり多層化し，後記する ${ }^{3} \mathrm{H}-$ thymidine 取り込みの增加 と一致して多数の有系核分裂像を見，その強い増殖能を窅わしめると共に，分泌能の出現，すなわち，Call一 Exner bodies や卵胞腔の形成がみられた。他方，乙うした第三次卵胞の卵胞上皮直下の基底膜は完全に閉 鎖していた．また基底膜の外側には紡鍾形，類上皮様の細胞が数首の首形成をなし，卵胞を取り团み求心性 に配列していたが，てれが䓠膜細胞で，本層には血管網が認められた。このように明瞭な莢膜細胞は卵胞の 卵腔形成周辺期に出現したか；，卵透明帯の形成もこの時期から明確化する．第三次卵胞の卵細胞は第二次卵 胞の夫よりさらに增大し，ほぼ成熟卵胞卵大に達し，Mallory Azan 染色で透明帯や卵胞液は青染していた。

他方，間質ではことに荻膜細胞と隣接する部位で著明に肥大した間質細胞が島状又は円錐状の細胞集団と して分布していた。

てれが第一次間質腺で，その細胞周囲は微細な嗜銀線維に囲まれ，後述する第二次間質腺細胞にくらべ， 胞体はより eosin 箸好性で，核/原形質比はより大であつた。また，乙の時期以降門部に中等大血管が出現 した。

B 組織化学的所見：脂質顆粒は萊膜層に断続的に存在し，てとに第一次間質腺に豊富に認められたが，

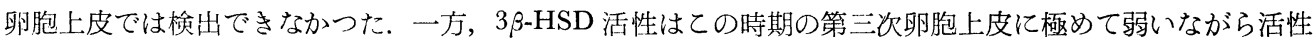
をみとめ,また第一次間質腺では強い,莁膜細胞では中等度の活性が見られた。また間質腺の脂質と $3 \beta-H S D$ 活性の出現時期の相関を明らかにすべく11日目卵栄を検討した結果， $3 \beta-H S D$ 活性は陽性であつたが Sudan black 陽性顆粒は陰性であつた，LDH 活性は第三次卵胞上皮，第一次間質腚に強い活性を見，ことに卵胞 腔に接する上皮細胞程強く，外側部は弱かつた。まま莢膜首の活性は卵胞細胞より弱かつた。

これに対し，G-6-PDH 活性は第一次間質腺では極めて強く，卵胞上皮の活性は卵胞の発育度と比例して 弱いながら増強し，莁膜細胞では卵胞上皮より活性の明かに高い部位と弱い部位とが混在し，肧上皮の活性 は極めて低かつた。

C. Autoradiograph 所見 : migration 法では卵胞上皮の他に萊膜細胞，第一次間質腺細胞にも ${ }^{3} \mathrm{H}-$ thymidine の移動が見られ，このことから荻膜細胞や第一次間質腺細胞が未分化間質細胞に由来するととが示 唆された。

他方 pulse labeling 法による泼上皮，原始卵胞，第一次卵胞，第二次卵脆の thymidine index は Table 2 の様で，7日目の畉巣に比して減少していたが，第三次卵胞上皮のみは $25.2 \%$ と明らかに高値を示し，英 膜層は未分化間質細胞より低い值を示した。また，第一次間質腺細胞には ${ }^{3} \mathrm{H}$-thymidine 陽性:紐胞と陰性細 胞とがあり，陰性細胞は総じて肥大した胞状の原形質を持ち， $3 \beta-H S D$ 活性もより豊富の様であつた。

\section{5 生後21日目の卵巣}

A 組織学的所見 : 卵胞の発有状況はFig. (2)の様で, 卵胞上皮細胞数101〜140の第三次卵胞が最も多く,ま た，少数であるが卵丘をもつ卵胞も認められた．また閉鎖卵胞もこの時期から出現した，一方，原始卵胞は 著るしく減数していた，そしててのような卵胞発育に平行し内莢膜細胞もより肥大し，その㐿内細毛管系の 発達もより顕著となつた．また間質では，第一次間質腺の他に中心部に腔を形成し，核の円形で，核，原形 質比は小さく，細胞質の胞状かつ明調な細胞集団が出現した。乙れが第二次間質腺で，第一次間質腺と異つ て本組織では全く有糸核分裂像を譛めなかつた。さらに閉鎖卵胞から第二次間質腺への移行像としてほぼ次 


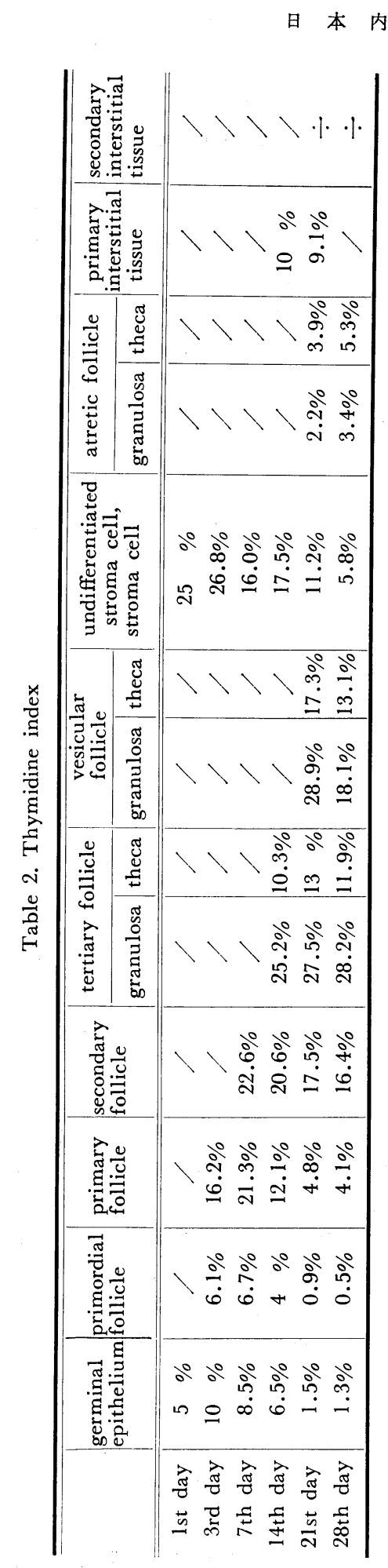

の如き 3 段階の像が認められた。 即ち, 先ず基底膜層 が肥厚又は不明膫化し, 顆粒膜細胞首に膠原線維が侵 入し, 苏膜細胞の肥大, 増殖が認められる (type 1), 卵胞上皮細胞の一首の変性所見の他飞著明な荻膜細胞 の肥大，増殖か認められるもの(type 2)，ついで，腺 腔に接して顆粒膜細胞基底膜がなお明膫に遺残してい るが, 内莢膜細胞は間質腺細胞様に肥大している像 (type 3) などである.

B 組織化学的所見 : 脂質顆粒の存在部位は第一次 間質腺, 第二次間質腺, 莢膜細胞層, 閉鎖卵胞などで あり, 莢膜細胞層の顆粒密度は, 卵胞の大きいもの程 高く, 発育卵胞の顆粒膜細胞は閉鎖卵胞と異なり脂質 を証明できなかつた，他方間質腺では最強の反応が得 られた. $3 \beta$-HSD 活性も 14 日目の卵巣に比し急增し た. すなわち, 莢膜細胞, 第一次間質腺, 第二次間質 腺, 少数の閉鎖卵胞の顆粒膜細胞に強い活性が検出で きたが，14 日目の卵栄の小型第三次卵胞でみられた $3 \beta$-HSD 活性はての時期以後消失し, 莢膜細胞層では 卵胞発育に比例して卵胞の周囲にそい，断裂状に反応 を示すものから卵胞の全周にわたり検出できるものも あつた，一方，間質腺の反応組織量も増していた。 ま た，第一次間質腺と第二次間質腺との活性を比較する と, 後者の反応組織量がより多かつた.

G-6-PDH 活性の反応部位は莢膜細胞層, 第一次間 質腺, 第二次間質腺, 顆粒膜細胞首で, また第一次, 第二次間質腺の活性強度は単位組織量当りでほぼ等し かつた.

一方, LDH 活性は第二次間質腺で最も強く，原始 卵胞においても， G-6-PDH 活性に比して明らかに強 い活性を認め，肧上皮にも活性か認められた。

C Autoradiograph 所見 : pulse labeling 法によ る ${ }^{3} \mathrm{H}$-thymidine の取り込みは第二次間質腺ではこれ を欠くのに対し，第一次間質腺では取り込みがみられ た. また，第三次卵胞上皮の index は高く，特にて の時期の胞状卵胞は最高の值を示した．他方閉鎖卵胞 の取り込みは有意に減少していた。

一方，生後 16 日目に ${ }^{3} \mathrm{H}$-thymidine 老腹腔内投与 $(2 \mu \mathrm{ci} / \mathrm{gr})$ した21日目の所見 (migration 法)では第二 次間質腺細胞への ${ }^{3} \mathrm{H}$-thymidine の移動が証明でき た. 木所見は第二次間質腺が閉鎖卵胞の内莢膜細胞か 卵胞絊胞に由来寸るとと老意味する。

\section{6 生後28日目の卵果}

A 組織学的所見 : 生後21日目の卵菓に比して間憵 
結合織や血管系が増加し, 卵胞の発育はさらに進み, 閉鎖卵胞も増加し, 間質腺の占める割合も急激に増加 していた．また，21日目卵栄と異なり第一次間質腺は消失し，第二次間質腺が間質腺の主体をなし，多数の 霊胞化間質腺か認められた.

B 組織化学的所見：脂質は莢膜細胞，閉鎖卵胞，間質腺に陽性で，その反応強度については莢膜層での 顆粒密度は21日目の卵巣と比べほぼ同様であつたが，間質腺は明らかに高かつた， $3 \beta-H S D$ 活性も脂質顆粒 とほぼ同様な分布を示したが，H.E.所見上，閉鎖卵胞と見做し難い大卵胞の顆粒膜基底層にしばしば $3 \beta-$ HSD 活性が出現し, 同部の G-6-PDH 活性も強い反応を示した。.また G-6-PDH 活性はての時期以降胞状 卵胞卵にも出現し，LDH 活性はむしろ減少の傾向がみられた。他方明らかに閉鎖過程の進行した，粗大な 脂質顆粒を証明できる変性卵胞上:皮では本酵素を証明できなかつた。

C. Autoradiograph 所見: 原始卵胞上皮の ${ }^{3} \mathrm{H}$-thymidine index は殆んぞ消失し, 第一次卵胞, 第二 次卵胞での index もてれ以前の時期に比しやや減少する傾向にあつた。

てのほか, 胞状卵胞も21日目の夫に比し，取り込みは明らかに減少しており，本所見は $3 \beta-H S D$ 所見と あいまつて卵胞の成熟，機能分化を示唆する．また，第二次間質腺では全くとり込みを欠いていた。

胚上皮の取り込みの推移に関しては上皮の一層の薄化（Fig. 1) と共㵊低值を示した.

\section{7 生後40日，54日目の卵巣}

A 組織学的所見：卵胞はさらに発育し，乙とに皮質周辺に多数の霻胞卵胞をみ，間質腺も増量していた. 黄体は生後54日目で出現していた。乙の時期の大卵胞では内萊膜風のいわゆる thecal holding を見るもの もあつた，肧上皮は生直後の厚さの $65 \%$ 亿薄化しており, 卵坚の発育に逆比例してその厚さが減少するとい う結果を得た.

B 組織化学的所見：脂質， $3 \beta-H S D$ 活性は 28 日目の卵巣とほぼ同様な分布を示したが，黄体が出現する と, $3 \beta$-HSD 活性, 脂質の主反応部は黄体となつた。

また泼上皮の LDH 活性は明らかに娍少していた。

\section{III 考按}

Fig. 3 は生直後から性成熟期にかけての卵巣の形態学的変化をまとめたものであるが，ての成績から卵数， 卵胞の発育状況，間質腺の出現時期，その発育状態，胚上皮層などの所見が卵巣分化の形態学的指標となり， さらにてれら卵巣各組織要素間の動的移行を追加考察するととにより, より正確な把握が可能であるととが わかる。

卵細胞数の経令的な減少はすでに Zuckerman (1962) ${ }^{1)}$ 万, Johnes $(1961)^{2)}$ の研究で確立されているが, この卵減数現象と下垂体性 gonadotropin の相関につき, Johnes $(1961)^{3)}$ は垂剔マウスはその減数速度か遅 延すると報している，とてろで，乙のような卵减数現象は，著者の検索成績からも明らかなように新生仔期 に特に顕著で，乙の時期の卵減数機構に関し，Franchi ら（1962) ${ }^{4)}$ は卵変性やこれに付随してわてる phagocytosis 機構を重視しているが，てのさい先に述べた胚上皮経由业卵放出現象も同時に極めて重要な意義 を持つと思われる. その根拠は卵減数現象の顕著なての時期に多数の泼上皮内卵か認められたからである. 胚上皮中の卵細胞の存在が卵細胞産生組織としての肧上皮説の有力な根拠を提供したてとは述べるまでもな いが，卵放出を示唆する一連の組織学的過程，肧上皮自体に有糸分裂像を認めても，卵自体の有糸分裂を欠 き，また同時期の卵管内に卵細胞を検出できた林ら $(1971)^{5)}$ の成績に鑑み，本所見は卵放出過程の一断面 をとらえたものと考えられる。

肧上皮自体の経令的変化に関しては，生直後は傮重首を呈し，高円柱状であつたが，生後一週から明膫な 単首の立方上皮となり，䐦開口期前後ではむしろ扁平化し，その LDH 活性も生後日数を経るに従い減少し たが，乙の所見はVincent $(1948)^{6)}$ の結果とほぼ符合する.

つぎに，卵細胞の核分裂状態とその分離現象について考察すると，生直後群集密在する卵細胞の核分裂状 態は eary prophase stage, ことに diplotene stage にあるものが多く, 生後 3 日目で卵細胞が分離しはじ 
Fig. 3
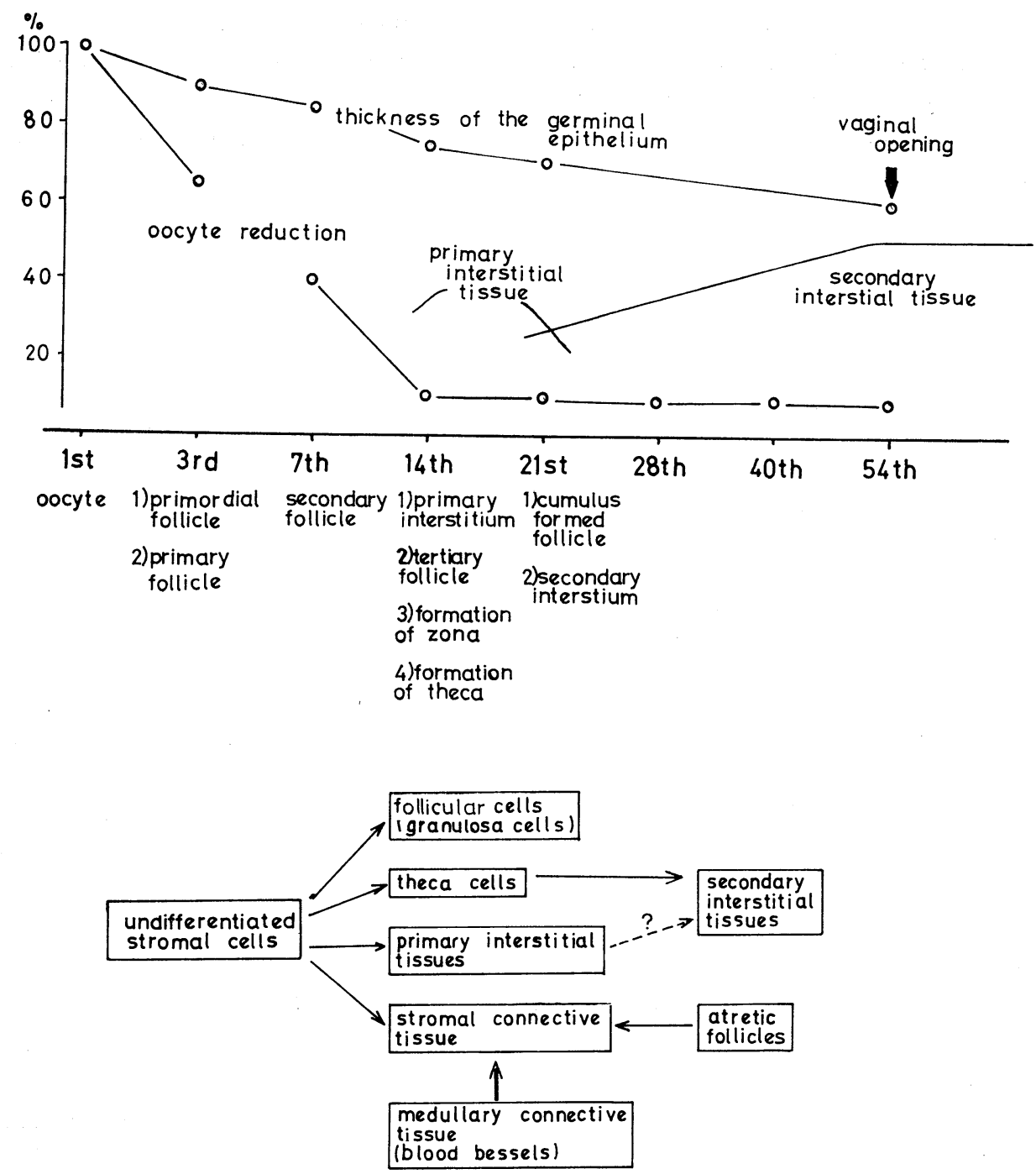

めると同時にその多くは dictyate stage に移行していた.

この成績は生直後のマウス卵細胞を検討した Peters $(1969)^{7)}$, 生後 $3 \sim 4$ 日目ラット卵細胞について観察 した Mandel ${ }^{4)}$ らの結果とほぼ一致しており，また Franchi $(1970)^{8)}$ もヒト卵細胞は胎生20〜30週頃から， late pachytene, さらに diplotene stage に移行するが， 卵細胞への卵胞細胞の完全な付着，すなわち，原 始卵胞の形成はその核分裂が late pachytene, 又は diplotene stage に移行するまで決しておてらないと述 べている．したがつて，卵細胞の核分裂状態はその分離と極めて密接な関係のあることがわかる．また卵相 互間の核分裂の同調傾向の機序に関し卵胞形成以前の時期において, Weakly $(1967)^{9)}$ はハムスター,Zamboni $(1968)^{10)}$ は家鬼, Stegner $(1970)^{11)}$ は人で夫々卵相互間の紼胞間橋の存在を報じているが極めて示唆に富 む報告である.

つぎに, 卵胞の生後発育過程に関し生後 3 日目から原始卵胞と第一次卵胞の出現を, 7 日目前後から第二 
次卵胞，第14日目前後で第三次卵胞の出現を見たが，卵胞形成初期段階での興味ある所兒として，preprimordial follicle の卵胞上皮は pulse labeling 法で，ほぼ未分化間質細胞に近い高い取り込みを示した。し かし原始卵胞や第一次卵胞の取り込みは低く, 卵胞細胞が未分化間質細胞に由来するという著者の見解から すれば，本所見は未分化間質細胞の contact differentiation を意味すると思われる．乙の点中井 $(1971)^{12)}$ は一日令の原始卵胞上皮で高い取り込みを兒ているが，ての成績は未分化間質細胞をも計数した可能性がつ よい.

しかし，その後の発育段階における卵胞上皮の thymidine 取り込みはその発育の進展，すなわち第二次， 第三次卵胞の順により高くなり, 卵胞の增大が卵胞液の急激な貯溜に基く囊胞状大卵胞では却つて減少した. また卵胞細胞の発育と卵細胞発育の相関に関する著者の成績では，原始卵胞，第二次卵胞，第三次卵胞と卵 胞の発育に平行し，卵細胞直径は増大し，ほぼ第三次卵胞で成熟卵胞卵細胞大に達した。一方，卵胞上皮の 組織化学的所見をみると, 生後 7 日目頃の原始, 第一次, 第二次卵胞の卵胞上皮で強い LDH 活性がみられ たが， $3 \beta-H S D$ 活性は極めて弱く，乙のととから，乙の時期の小卵胞上皮の糖代謝は嬚気的解糖系が主体を なすと推察されたが，生後14日目では Pentose Monophosphate Shunt 上の key enzyme である G-6-PDH 活性が第三次卵胞上皮に出現し，同部に見られる ${ }^{3} \mathrm{H}$-thymidine 取り込みや核分裂像の増加とあわせ考光， このような G-6-PDH 活性の急激なかたまりは主として五炭糖回路からの Ribose-5-Phosphate の核酸合成 に関与すると推定できたのみならず, G-6-PDH 活性の出現する第三次卵胞以後では急激な卵胞直径の増大 が見られないので, 卵細胞発育に関与する嫌気的解糖系のもつ重要性も示唆された。

また14日目第三次卵胞の卵胞上皮に微量の $3 \beta$-HSD 活性を証明できたが， ての知見は Presl (1970) ${ }^{13)}$ ら の成績と異なり，Brandau (1970) ${ }^{14)}$ の結果と一致しており，ての意義に関しては不明である．もちろん，本 所見は生後28日頃にあらわれる胞状卵胞の周辺顆粒膜風にみられる $3 \beta-H S D$ 活性とは脂質, G-6-PDH 活性 を欠く点異賈の性格をもつもので，後者は周知の通り卵胞上皮のルテイン化と見做されている．（Amorosso， $1955^{15)}$ : Bryans, $1955^{16}$ : Jirásek, 1970 ${ }^{13)}$.)

次に菼膜細胞層の形成に関し第二次卵胞ではその形成は明瞭でなく，一部の卵胞に一層の epitheloid 様 細胞の荻膜層様の配列が見られたが，本細胞は脂質顆粒，3 $\beta$-HSD 活性院性であつた。しかし第三次卵胞で は明瞭な萊膜細胞層が出現し，乙の内荻膜細胞には $3 \beta$-HSD 活性陽性細胞と陰性細胞とがあり，また Pap 染色で血管網の形成がみられた。 この成績は内莢膜の分化が antrum formation の時期に相前後しておてる と言う Brambell $(1928)^{17)}$, Harrison $(1962)^{18)}$, Peters $(1969)^{7)}$, Jirásek $(1970)^{13)}$ らの結果と符合する。た だ，最近 Stegner $(1970)^{11)}$ はマウス卵巣で Pedersen (1968) ${ }^{19)}$ らの規定する type 3a 卵胞に微細構造所 見上内莢膜細胞の分化を見ているが，てれは著者の前述した $3 \beta$-HSD 活性陰性の類莢膜細胞に相当するも のと思われる。

また Dawson (1951) 20) はラット卵巣の生後18日目までの theca は Shiff 反応, Schultz 反応共に陰性で, 内分泌学的に non-reactive としているが, Jirásek $(1970)^{13)}$ ら, Küpper (1967), Schlegel $(1967)^{22)}$ は生後 10日〜14日の腔形成卵胞の theca 亿 $3 \beta$-HSD 活性を認めており，乙の点を考虑し第一次間質媳を慎重に除 外した著者の本実験でも， $3 \beta-H S D$ 活性の局在を証明できた。

つぎに，第一次間質腺の形成は第三次卵胞の出現に相前後して，不規則な島嶋状，あるいは円錐状に分布 する epitheloid 様の細胞集団として出現したが，ての部位は極めて強い 3 $\beta-\mathrm{HSD}$ 活性, 脂質顆粒, G-6-PDH 活性を保有し， steroid 産生組織と推定できた。 また本組織は内苏膜て比し G-6-PDH 活性が総じて明かに 強く，また ${ }^{3} \mathrm{H}$-thymidine とり込みがやや低い。

乙の成績は Rennels (1951) ${ }^{23)}$ やDawson (1951) ${ }^{21)}$ のラットを用い Schiff, Schultz 反応陽性, Sudan 好 性の間質腺組織が生後 10 日目頃から出現するという報告，さらに $3 \beta$-HSD の局在を指標として検討した Jirásek $(1970)^{13)}$, Schlegel (1967) ${ }^{22)}$ らの結果と一致するものである.

ところでこのような steroid 產生能をもつ内荻膜又は第一次間質腺細胞の出現と関連し, 新生仔期卵巣の 内分泌機能に関する従来の諸家の見解をててであわせ考察してみると，ての時期卵笌は機能的に静止状態に 
とどまり，少くとも生後10〜20日目までは外因性，下垂体性 gonadotropin や PMS に反応せず，第三次卵 胞以前の卵胞の発育過程には gonadotropin を必要としないとの見解が有力であつた ${ }^{1), 24), 25)}$. しかし生後 1 〜 5 日で去勢したラットに去勢前葉の形成をみた Presl (1963) の報告 ${ }^{26)}$ ，また第三次卵胞や第一次間質腺 が出現する生後 8 日目から血中 estrogen をはじめて検出した Presl (1967)，の成績27)，さらに radioimmunoassey 法で血中 LH 含有量を測定し，生後 7 日以後急激に増加するという Weisz $(1970)^{29}$ 万の報告はい ずれも生後10日以内に下垂体性 gonadotropin の放出を生じ，しかもその刺戟のもとに卵巣性 estrogen が 分泌され，下垂体，性腺相互間には feed back 機構すら存在するてとを示唆している. 著者も ${ }^{30}$ ) 生後 3〜 7 日間 NIH-FSH-S 7 を連日投与し生後 7 日目卵巣で卵胞細胞の LDH 活性の急岐な増加や，ほぼ14日目に 相当する卵胞発育をみており，しかもての際第一次間質腺細胞の形成は顕著でなかつた。 との結果は antigonadotropin を同時期に投与した Lunenfeld の成績（1970) ${ }^{31)}$ とほぼ符合する.したがつてての時期卵巣 の gonadotropin 依存性は前記した第二次間質腺が出現し，閉鎖卵胞の出現する生後20日目前後に比較する とはるかに低いにしても, 新生仔期卵巣の形態分化に対し, gonadotropin が極めて重要な役割を演じるて とが推定できた.

とてろで, 卵胞, 内膜, 間質細胞の組織由来に関しては従来定説を欠き, 卵胞細胞の組織由来については, 1) 胚上皮説，2）間葉細胞説，3）その混合説，4）いわゆる blastema 説，内膜細胞に関しては，1) 間質細胞説，2）間質腺細胞説，さらに間質腺細胞では，1）肧上皮や卵胞細胞をもふくめた上皮説，2） 間質細胞説，3） medullary cord 説，4）内莢膜細胞説などの偝説方唱えられていた ${ }^{1), 32), 33)}$. しかしなが ら, これらの諸説は, 通常の組織発生学的または比較解剖学的検索手段を主体としたものであるから, 動的 過程の追跡という見地から自ずと一定の制約が残されていた.

そこでこの点に注目し著者の migration 法を併用した結果を記述すると次の様である.

まず，卵胞，内膜細胞の細胞由来に関しては，1）生直後の卵栄で，卵細胞を囲繞する未分化間質細胞に 強い ${ }^{3} \mathrm{H}$-thymidine のとり込みをみ，2）乙れが夫々卵胞上皮，内膜細胞に移動し，3）少くとも生後では 肧上皮のいわゆる down/growth 像の認められないなどの理由から, マウスを用いたPeters $\left(1967^{77}, 1969^{34)}\right.$ ) の成績と同様に, 両細胞は未分化間質細胞という共通の細胞から分化するであろうとの見解を得た.

また，間質細胞に関しては，第一次間質腺と第二次間質腺とで全く異なる結果を得，前者は未分化間質細 胞，後者は内萊膜細胞に由来すると見なし得た。乙の際第一次間質腺に関しては，基底膜閉鎖以前の時期に， 間質組織に向い円錐状に突出する卵胞上皮細胞集団が卵胞から離脱, 間質腺化する可能性を考慮する必要も あるが，電顕的に 5 日目未分化間質細胞（マウス）では steroid hormone 分泌細胞としての移行的な超微細 構造をすでに具備しているというStegner (1970) の報告 ${ }^{11)}$ とわせ考える時，やはり未分化間質細胞に由 来すると考光るのが妥当であろう.

他方本細胞は生後28日目の卵巣では消失していたが，その詳細に関しては今後検討の余地が残されている.

また，第二次間質細胞の由来については第三次卵胞の開鎖の出現に一致して，第二次間質腺か現われ，ま た migration 法のみの成績では内膜細胞のほが卵胞細胞由来を除外できなかつたが，同時に閉鎖過程の推 移を追跡するととにより，本組織は閉鎖時に增殖，肥大する内莢膜細胞から transform するという Rennels (1951) ら ${ }^{23)}$ と同一の見解が得られた.

最後に生後日数をへるに従つて pulse labeling 法による間質細胞の thymidine index の低下をみたにか かわらず，特に生後21日以後間質組織の著しい增量がるられたことは，ての時期を境として間部血管が激増 するという事実とあわせ考えて，ての時期にみられる結合織の増量が in situ mesenchym の分裂增殖に依 存せず，恐らくは内部血管の侵入に伴うその随伴性結合織に大きく依存しているてとを想起せしめる.

しかし，乙のほか閉鎖卵胞が生後21日目頃から出現する点, 卵胞閉鎖に起因する結合織の増量の可能性も 否定できない.

稿を終るにあたり，終始御想篤なる御指導ならびに御校閲を賜りました東條伸平教授，また直接の御指導， 
御鞭撻を載いた林要助教授に深甚なる謝意を捧げます. 又研究面で貴重な御教示, 御協力を睗りました本学 第二解剖学教室溝口史郎教授, 菊井悠充先生に深謝します。また数々の御助言, 御協力を頂いた協同研究者 の鴐尾元夫先生, 武木田博祐先生, 谷立夫先生, 及び川辺氏，笠谷氏に感謝致します.

(本論文の一部は昭和 46 年 6 月, 第 4 回近畿核医学研究会, 昭和 46 年 10 月第 7 回国際不妊学会, 昭和 46 年 10月第19回日本内分泌学会西部総会で発表した。）

\section{文献}

1) Franchi. L.L., Mandel, A.M. and Zuckerman, S. : The Ovary. vol. 1 (1962) 1, Academic Press, New York, London. $\quad$ 2) Johnes, E.C., and Krohn, P.L. : J. Endocr, 21 : 469, (1961). Johnes, E.C. and Krohn, P.L. : J. Endocr, 21 : 467, (1961).

4) Franchi, L.L., Mandel, A.M. : Proc. roy. Soc, $157:$ 99, (1962).

5) 林 要, 古結一郎, 武田博祐, 谷 立夫, 東條伸平 : 第 19 回日本内分泌学会西部部会総会, (1971).

6) Vincent, W.S. : Am. J. Anat, 83 : 137, (1967). 7) Peters, H. : Acta. Endocr, 62 : 98, (1969).

8) Franchi, L.L. : Scientific Foundations of Obstetrics and Gynecology (1970), 107, William Heidemann Medical Books LTD. London. 9) Weakley, B.S. : J. Anat. 101 : 435, (1967). $\quad$ 10) Zamboni, L. \& Gondos, B.G. : J. Gell Biol, 36 : 276, (1968). $\quad 11)$ Stegner, H.E. : Gonadotropins and Ovarian development. (1970) 232, E \& S Livingstone, Edinburgh \& London. 12) 中井利昭：日産婦誌, $23 ； 397,(1971)$ 13) Jirásek, J.E., Presl, J., Horsky, J. : Acta Histochem. 37 : 162, (1970). 14) Brandau, H. : Gonadotropins and Ovarian development, (1970). 307, E \& S Livingstone, Edinburgh \& London.

15) Amoross, E.G. : Brit. Bull, 11 : 117, (1955).

17) Brambell, F.W.R. : Proc. Roy. Soc. 103 : 258, (1928). 11 (1962), 143, Academic Press," New York, London. Reprod. Fert, 17 : 555, (1968).
16) Bryans, F.E. : Endocr. 48 : 117, (1955). 18) Harrison, G. : The Ovary. vol

19) Pdersen, T., and Peters, H. : J. (1951). 21) Küppers, S. : Acta. histochem, $27: 267$, (1967). 22$)$ Schlegel, R.J., Farias, E., Russo, N.G., Moore, J.R. and Gardner, L.I. : Endocrinology, 81 : 565, (1967).

Rennels, E.G. : Am. J. Anat, 88 : 63, (1951).

25) Hisaw, F.L. : Physiol. Rev., 27 : 95, (1947). Jirasek, J. : J. Endocr, $26: 287$, (1963). I., and Henzl, M. : J. Endocr. $38: 201$, (1967).

24) Smith, P.E. : Am. J. Anat, 45 : 205, (1930). 26) Presl, J., Horsky, J., Henzl, M., and 27) Presl, J., Horsky, J., Henzmann, J., Mikulas, 29) Weisz, J., and Ferin, M. : Gonadotropins and Ovarian development (1970), 339, E \& S Livingstone, Edinburgh \& London, 30) 林 要, 古結一郎：日産婦誌，投稿中，(1972)。 31$)$ Lunenfeld, B., and Eskhol, A. : Proceeding of 6th World Congress on Fertility and Sterility, (1970), 148, Gordon and Breach, New York and London. $\quad 32$ ) Brambell, F.W.R. : Marschall's Phisiology of Reproduction. vol 1. part 1, (1969), 511, Longmans, London. $\quad 33$ ) Fischel, A. : Z. ges. Anat. abt. 1., $92: 34$, (1930). 


\section{Explanation of Plate}

Fig. 1 : Ovary at birth (H.E. stain) $\times 140$

The ovary consists of oocyte, undifferentiated stromal cells, and pseudostratefied germinal epithelium.

Fig. 2 : Ovary at birth (Pap stain)

In the outer layer of the cortex, oocyte in the late prophase stage are aggregated ( $\downarrow)$, surrounded by Gitter fibers.

Fig. 3 : Ovary at birth (autoradiograph) $\times 280$

Autoradiograph of the ovary two hours after injection of ${ }^{3} \mathrm{H}$-thymidine on the day of birth. The oocytes are unlabelled but many stromal cells are labelled and the cells of germinal epithelium are labelled also.

Fig. 4 : Ovary of a 3 day old rat (Pap stain) $\times 280$

The oocyte are beginning to be separated each other. Maceration $(\downarrow)$ of argentophil fibers immediately below the germinal epithelium are observed. (Refer to Fig. 2)

Fig. 5 : Ovary of a 7 day old rat (autoradiograph) $\times 280$

By the migration method. The epithelium of primodian follicle is labelled. $(\downarrow)$

Fig. 6 : Ovary of a 3 day old rat (Pap stain) $\times 140$

In addition to primodian follicles and primary follicles, secondary follicles begin to appear.

The basement membrane of the secondary follicle is incomplete $(\downarrow)$, and the boundary with the interstitial cells are not distinct. The nuclei of oocyte has shifted to the dictyate stage.

Fig. 7 : Ovary of a 7 day old rat (H.E. stain)

The oocyte is thrown out through the germinal epithelium into the periovarian space.

Fig. 8 : Ovary of a 7 day old rat (H.E. stain)

The oocyte is covered only by some cells of the germinal epithelium.

Fig. 9 : Ovary of a 7 day old rat (LDH activity)

Activity is approved in the germinal epithelium $\left(\downarrow^{1}\right)$, oocyte $\left(\downarrow^{2}\right)$, follicular epithelium $\left(\downarrow^{3}\right)$, and undifferentiated stromal cell $\left(\downarrow^{4}\right)$. Activity of the primodian follicle is rather stronger than that of the secondary follicle.

Fig. 10 : Ovary of a 7 day old rat (autoradiograph)

By the migration method. The secondary follicle have labelled follicular cells by ${ }^{3} \mathrm{H}$-thymidine and many of the stromal cells are also labelled.

Fig. 11 : Ovary of a 14 day old rat (H.E. stain) $\times 140$

The tertiary follicle with the cavity apeared. The basement membrane is complete, and the zona pellucida is formed distinctly. (compared with Fig. 6)

The diameter of oocyte becomes larger. (compared with Fig. 6)

Fig. 12 : Ovary of a 14 day old rat ( $3 \beta$-HSD activity)

Activity in the tertiary follicular cells is weak, but in the primary interstitial tissue is strong. The thecal cells show moderately increased $3 \beta$-HSD activity. The germinal epithelium show no reaction.

Fig. 13 : Ovary of a 14 day old rat (G-6-PDH activity)

The primary interstitial tissue shows extremely strong reaction. The thecal cells $(\downarrow)$ generally show an evidently strong activity than that of the follicular cells. 
Fig. 14 : Ovary of a 14 day old rat (LDH activity)

The tertiary follicular cells show the strong activity, especially in the epithelial cells which are adjacent to follicular cavity. However, the activity of the primary interstitial tissue and the thecal layer is evidently lower than that of the follicular cells. Activity of the germinal epithelium is very strong.

Fig. 15 : Ovary of a 14 day old rat (autogradiograph)

The epithelium of tertiary follicle are labelled by ${ }^{3} \mathrm{H}$-thymidine and the thecal cells are labelled by migration method.

Fig. 16 : Ovary of a 14 day old rat (Pap stain)

Hypertrophic interstitial cells are distributed on the lateral side of the internal thecal layer, as the cells groups in islet form $(\downarrow)$. Follicular basement membrane is completely formed.

Fig. 17 : Ovary of a 21 day old rat ( $3 \beta$-HSD activity)

Activity in the thecal cells $\left(\downarrow^{1}\right)$, primary interstitial tissue $\left(\downarrow^{2}\right)$, secondary interstitial tissue $\left(\downarrow^{3}\right)$, and granulosa cells of atretic follicle is noted.

Fig. 18 : Ovary of a 21 day old rat (G-6-PDH activity)

Strong activity is noted in the thecal cell layer $\left(\downarrow^{1}\right)$ primary interstitial tissue $\left(\downarrow^{2}\right)$, secondary interstitial tissue $\left(\downarrow^{3}\right)$, and granulosa layer $\left(\downarrow^{4}\right)$.

Fig. 19 : Ovary of a 21 day old rat (sudan black stain)

Lipid granules are noted in the primary interstitial tissue $\left(\downarrow^{1}\right)$, secondary interststial tissue $\left(\downarrow^{2}\right)$, thecal cell layer $\left(\downarrow^{3}\right)$, and atretic follicles.

Fig. 20 : Ovary of a 21 day old rat (Pap stain)

The basement membrane of atretic follicle becomes hypertrophic $(\downarrow)$ or indistinct. Hypertrophy and proliferation of the thecall cells is noted (type 1).

( $\downarrow \downarrow$ follicles of the normal growth)

Fig. 21 : Ovary of a 28 day old rat ( $3 \beta$-HSD activity)

The secondary interstitial tissue $(\downarrow)$ is the main focus of $3 \beta$-HSD activity.

Fig. 22 : Ovary of Ovary of a 28 day old rat (G-6-PDH activity)

Strong G-6-PDH activity is approved in the internal thecal layer of the secondary interstitial cells. Follicular cells activity is evidently weaker than that of a 21 day old rat. The activity in the germinal epithelium is very weak.

Fig. 23 : Ovary of a 28 day old rat (Pap stain)

In addition to more degeneration of follicular cells, remarkable hypertrophy and proliferation of thecal cells are observed $(\downarrow)$. (type 2 )

Fig. 24 : Ovary of a 28 day old rat (Pap stain)

Basement membrane of granulosa cells adjacement to the glandular cavity rest distinctly. Intimal cells, are hypertrophic like interstitial tissue cells, pre-cystic form of the interstitial tissue. (type 3 ). 


$$
\text { 古結論文附网(その1) }
$$

Fig. 1

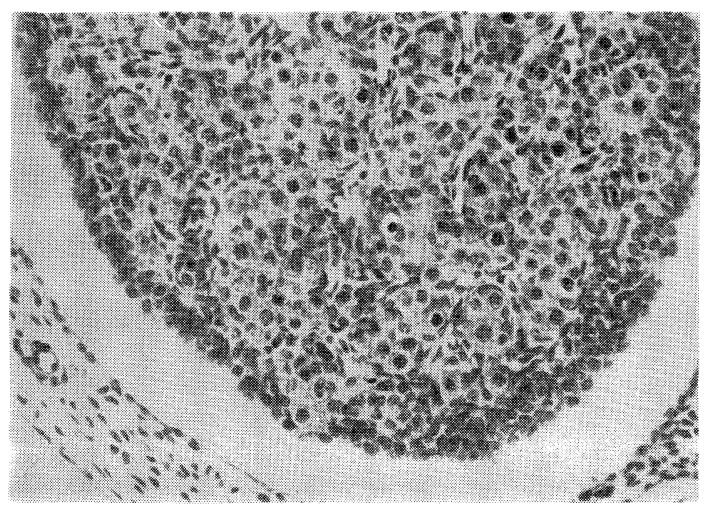

Fig. 3

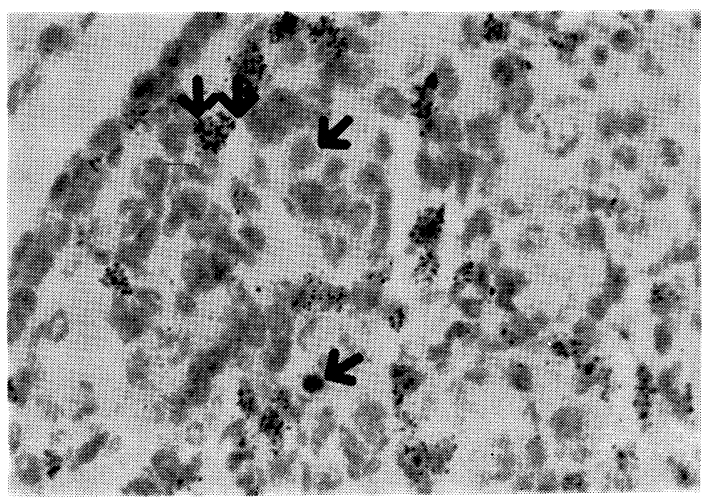

Fig. 5

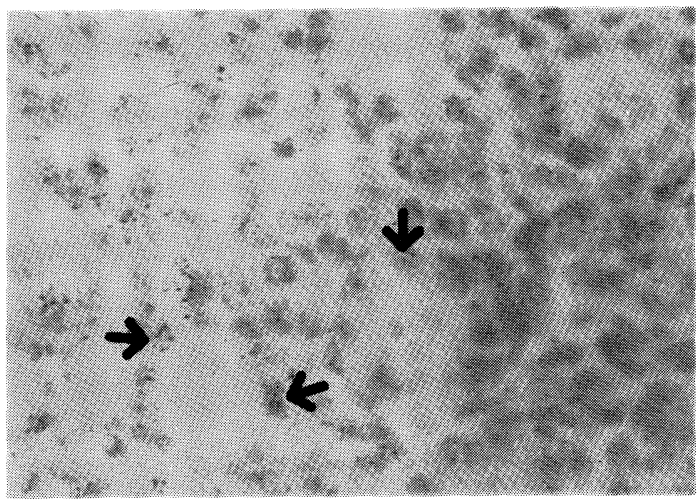

Fig. 2

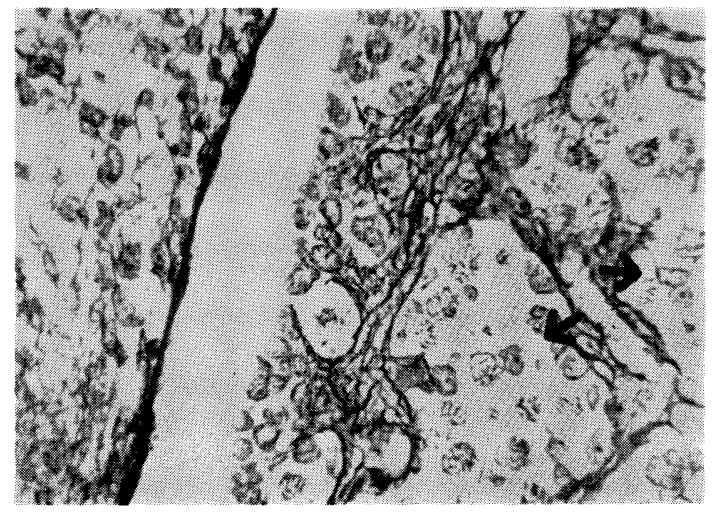

Fig. 4

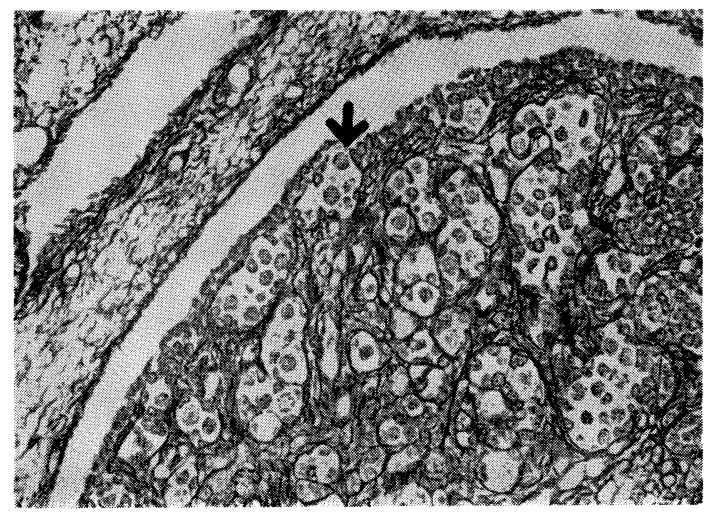

Fig. 6

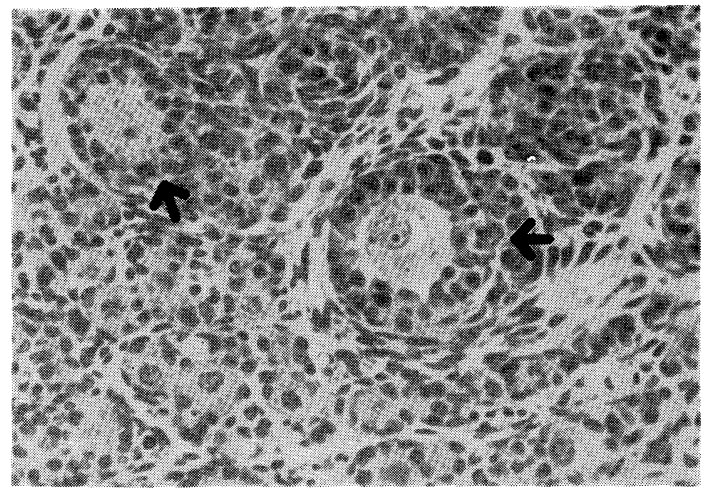


Fig. 7

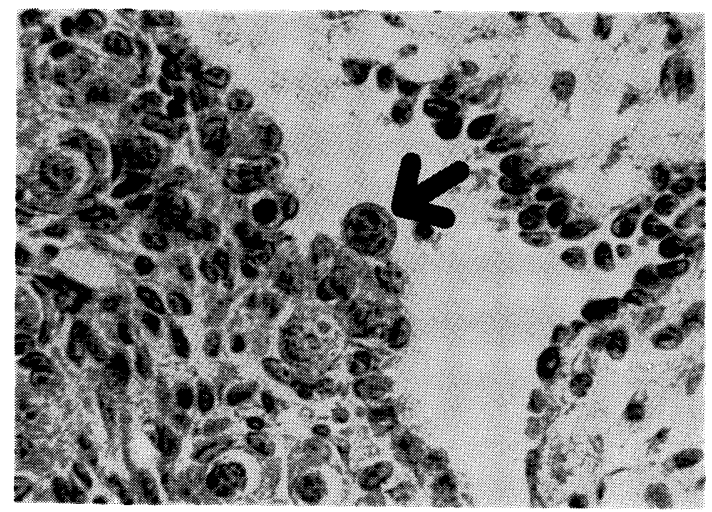

Fig. 9

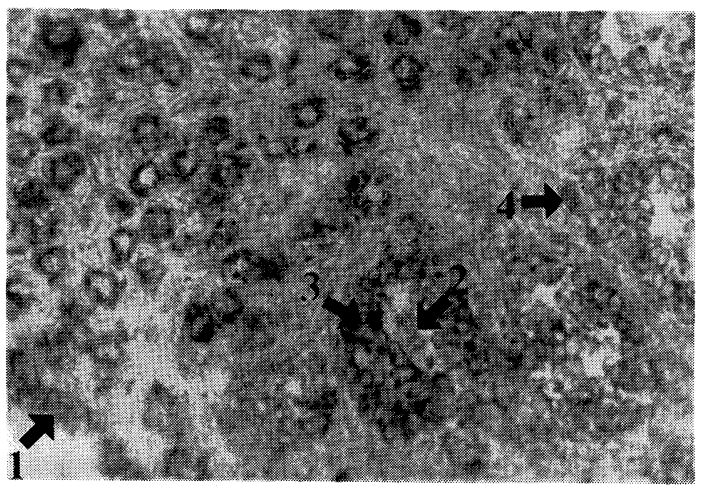

Fig. 11

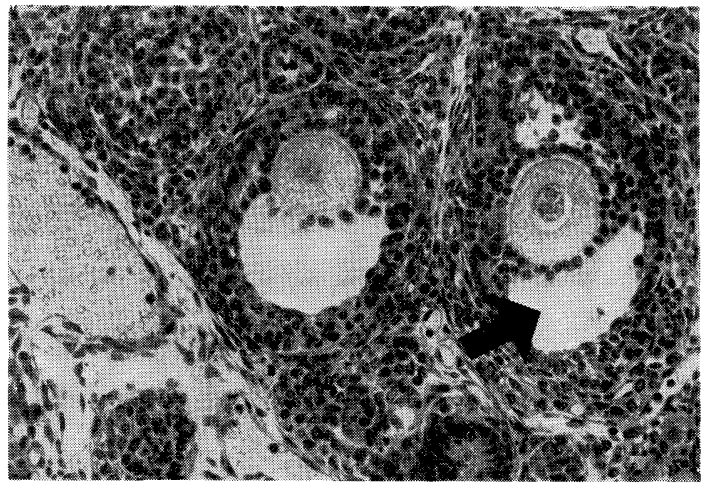

Fig. 8

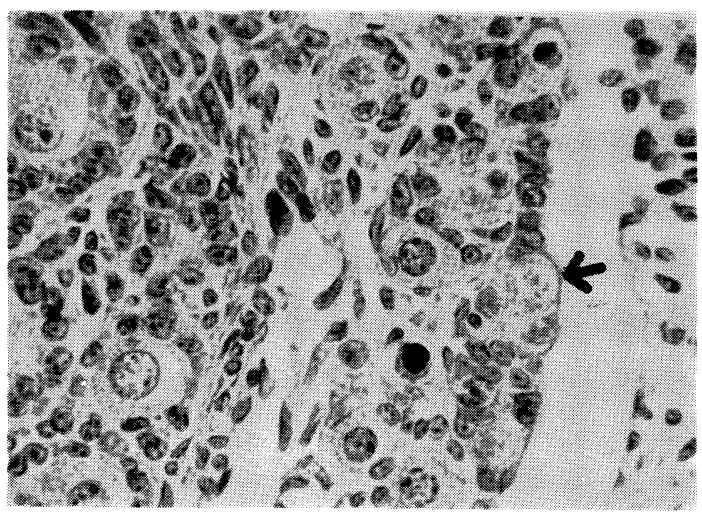

Fig. 10

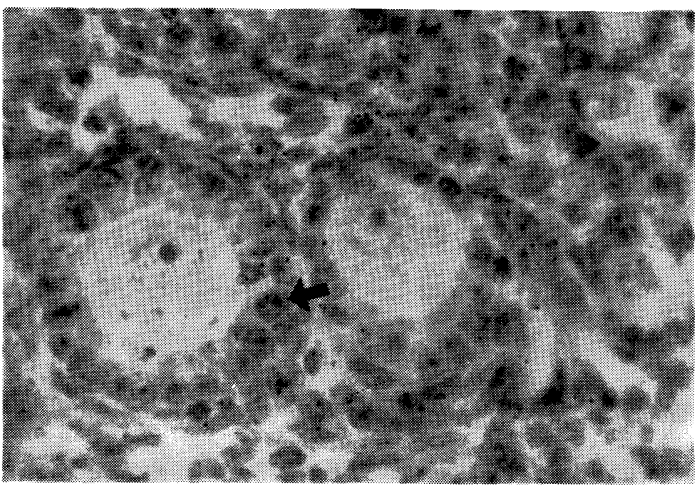

Fig. 12

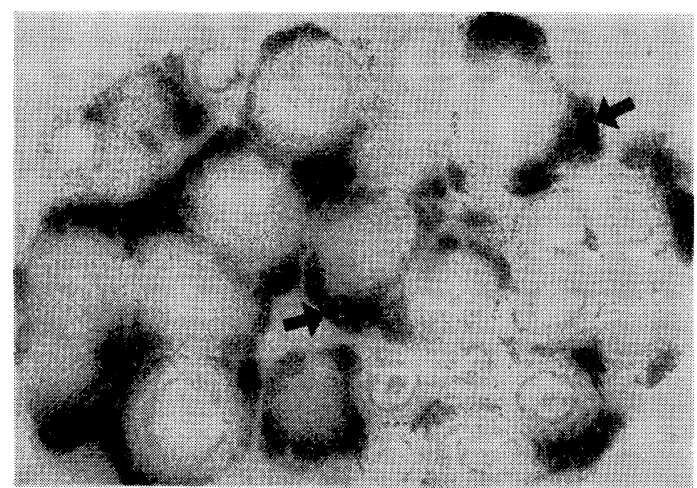




$$
\text { 古結論文附図( その 3 ) }
$$

Fig. 13

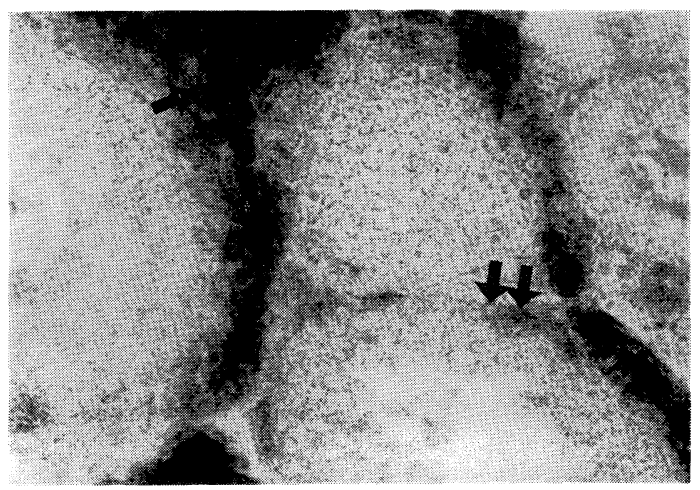

Fig. 15

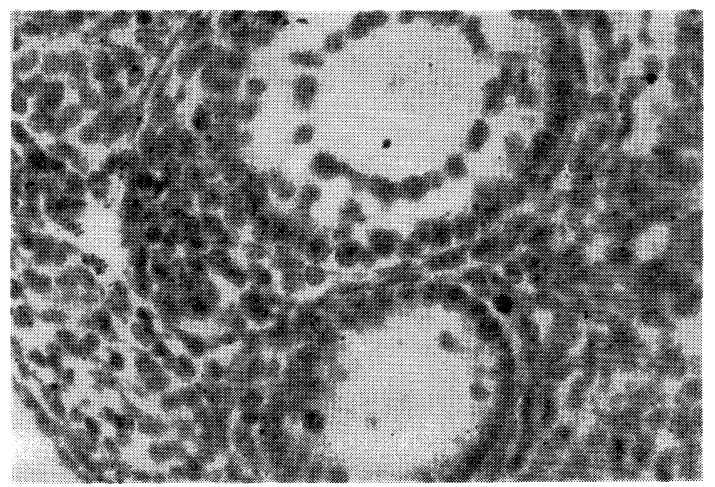

Fig. 17

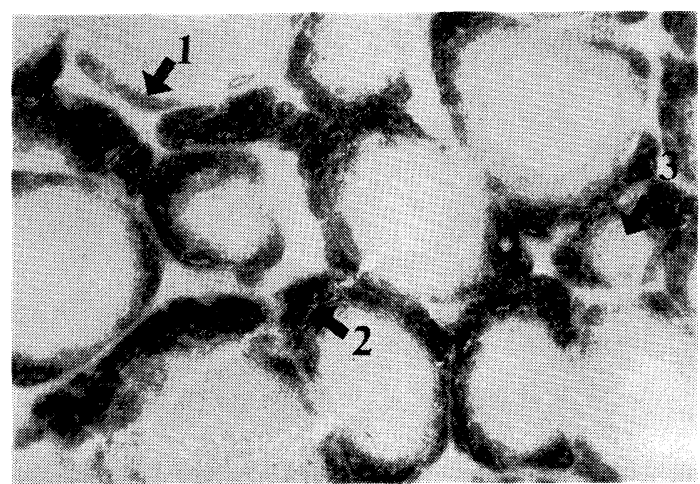

Fig. 14

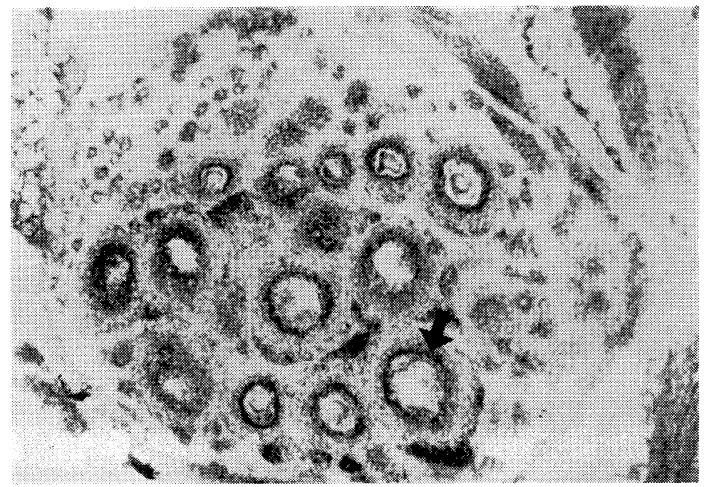

Fig. 16

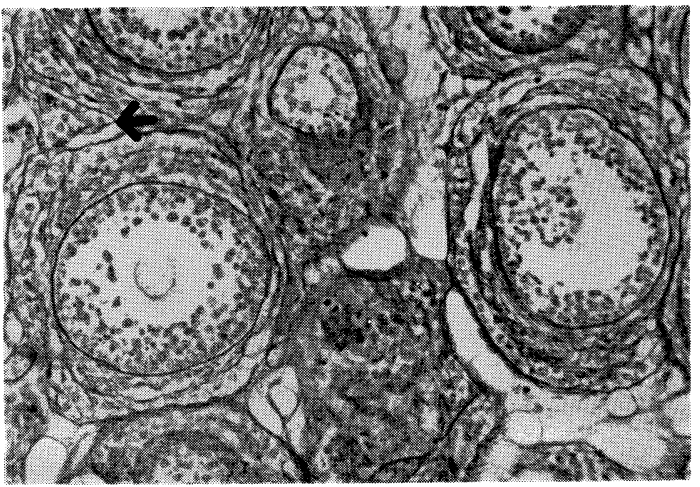

Fig. 18

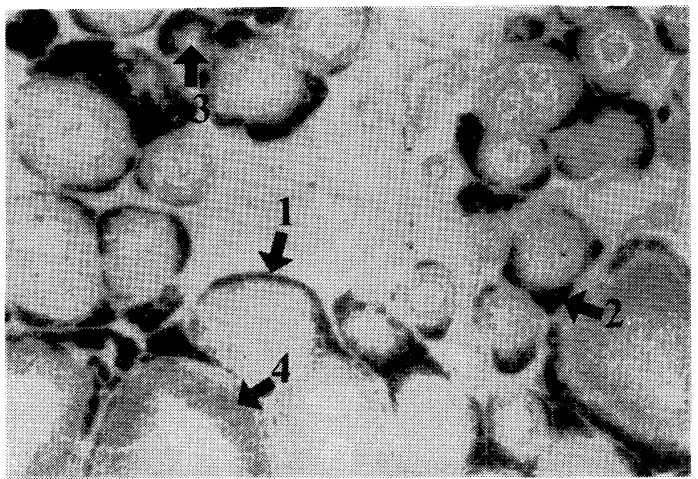




$$
\text { 古結論文附困(その4) }
$$

Fig. 19

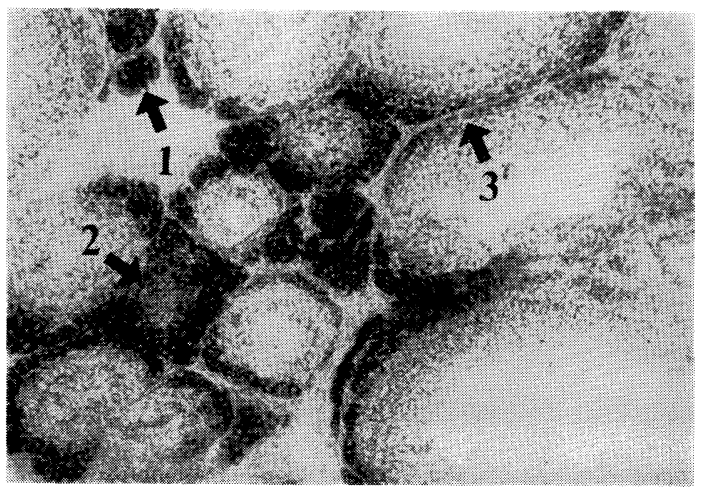

Fig. 21

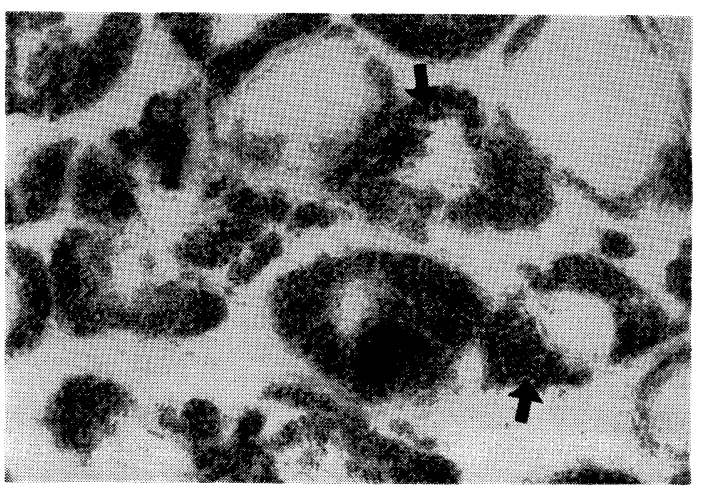

Fig. 23

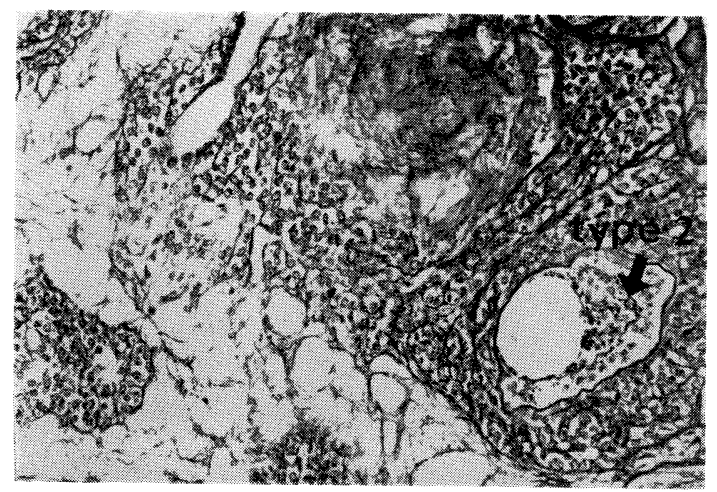

Fig. 20

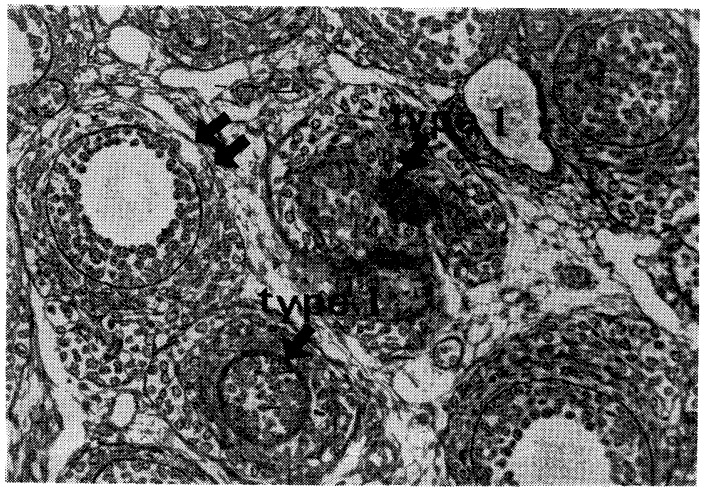

Fig. 22

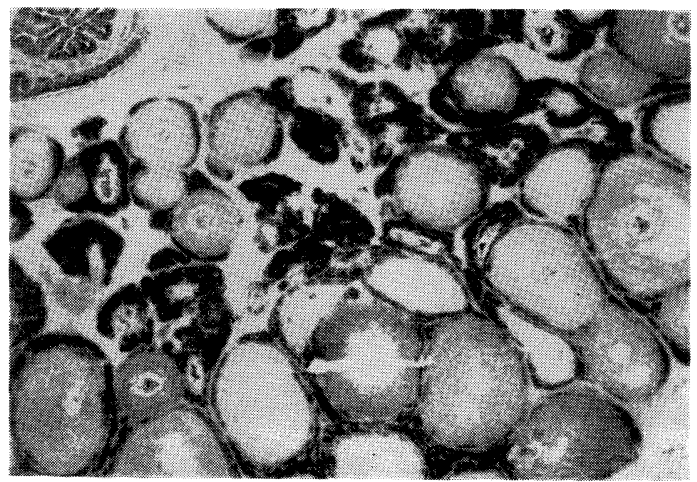

Fig. 24

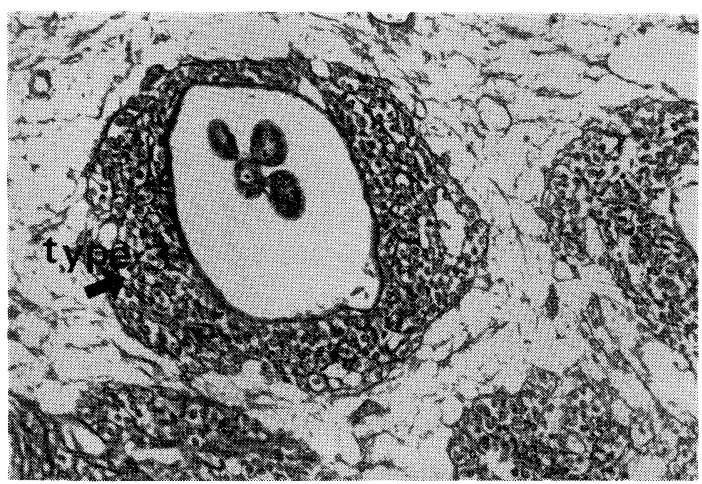

